\title{
Yeni Türkiye Bina Deprem Yönetmeliğine Göre Zeminlerin Sıvılaşma Analizi ve Sıvılaşmaya Karşı l̇yileştirilmesi
}

\author{
Uğur Dağdeviren ${ }^{1, *}$
}

${ }^{1}$ Kütahya Dumlupınar Üniversitesi, Mühendislik Fakültesi, Inşaat Mühendisliği Bölümü, 43100, Kütahya. ORCiD: 0000-0002-4760-6574

\section{Özet}

Depremlerin mühendislik yapıları üzerinde yol açtığı hasarlardan birisi zemin sıvılaşması kaynaklı hasarlardır. Zeminlerin sıvılaşma mekanizmasını etkileyen birçok faktör olmasından dolayl, sıvılaşma potansiyelinin değerlendirilmesi oldukça karmaşık bir problemdir. Deprem durumunda zeminlerin sıvllaşma hassasiyetinin belirlenmesi ve olası etkilerin önceden tahmin edilerek gerekli önlemlerin alınması gerekmektedir. Zeminlerin slvılaşma potansiyelini belirlemek için yaygın olarak kullanılan gerilme esaslı sıvılaşma analizi yeni Türkiye Bina Deprem Yönetmeliğine (TBDY) de dahil edilmiștir. Bu yöntemin kullanımında, depremin karakteristikleri, zemin özellikleri, arazi ve yeraltı su koşulları, arazi çalışmaları sırasında kullanılan ekipman özellikleri gibi çok sayıda parametreye ihtiyaç duyulmaktadır. Analizlerde kullanılan parametre sayısının ve ampirik ifadelerin fazlalı̆̆ nedeniyle, uygulamadaki zemin etüt raporlarında zaman zaman önemli hatalar meydana gelebilmektedir. Bu çalışmada, yeni TBDY'nde tanımlanan standart penetrasyon deneyine dayalı sivılaşma analizlerini pratik hale getirebilmek ve gerçekleştirilmiş analizleri hızlı bir şekilde kontrol edebilmek amacıyla, farkl derinlikler, yeraltı su seviyeleri, ince dane oranları ve standart penetrasyon direnci değerleri için kum zeminlerin sıvllaşmaya karşı güvenlik sayısını veren grafikler hazırlanmıştır. Buna ilave olarak, sıvılaşabilir zeminlerin iyileştirilmesine yönelik olarak zemin içinde kolon teşkili yönteminde kullanılacak kolonların rijitliği ve yerleşim sıklı̆̆ gibi tasarım parametrelerinin belirlenmesini să̆layan kartlar geliş̧tirilmiştir.

\section{Anahtar Sözcükler}

Sıvılaşma Analizi, Standart Penetrasyon Deneyi, Zemin İyileştirmesi, Jetgrout, Grafik Yöntem

\section{Liquefaction Analysis of Soils according to the New Turkish Building Earthquake Code and Improvement against Liquefaction}

\begin{abstract}
One of the damages caused by earthquakes in engineering structures is soil liquefaction-induced damages. Because of the many factors that affect the liquefaction mechanism of soils, the assessment of liquefaction potential is a rather complex problem. In the earthquake, it is the necessary to determine the liquefaction sensitivity of soils and take precautions by estimating possible effects. The stress-based liquefaction analysis, which is the commonly used to determine the liquefaction susceptibility of the soils, has been included in the new Turkish Building Earthquake Code (TBEC). In the usage of this method, the numerous parameters such as the earthquake characteristics, the soil properties, the in-situ and underground water conditions, the properties of equipment used during field studies are needed. Due to the excessive number of parameters and empirical expressions used in the analysis, significant errors can sometimes cause in the soil investigation reports in practice. In this study, in order to make practical use of liquefaction analysis based on standard penetration test defined in TBEC, and to control quickly the performed analyses, the graphics that give the factor of safety against liquefaction of sandy soils were prepared for different depths, groundwater levels, fine contents, and SPT-N values. In addition, cards were developed to determine design parameters such as the stiffness of the columns to be used in the column formation method and the column spacing to be used for the improvement of the liquefiable soils.
\end{abstract}

\section{Keywords}

Liquefaction Analysis, Standard Penetration Test, Ground Improvement, Jet Grouting, Graphical Method

\section{Giriş}

Depremler sırasında oluşan sismik tehlikelerin en önemlilerinden birisi zemin sıvılaşması sonucunda yapılarda gözlenen hasarlardır. Zemin sıvılaşması, özellikle suya doygun gevşek granüler zeminlerin tekrarlı yükler etkisinde sıkışma eğilimi göstermesinin bir sonucu olarak boşluk suyu basıncının artarak kayma direncinin kaybolması ve büyük şekil değişikliklerinin meydana gelmesi olarak tanımlanmaktadır. Sıvılaşma olayının gerçekleşmesi sonucunda, sığ temeller üzerine oturan yapılarda zemine batma, yan dönme gibi hasarlar oluşurken, yer altındaki çeşitli iletim hatlarının ise yüzeye çıkması ve bağlantı bölgelerinin hasar görmesi gibi sonuçlar ortaya çıkmaktadır. Ayrıca sıvılaşmadan kaynaklı olarak şevlerde akma türü göçmeler, düz ve az eğimli arazilerde ise yanal yayılma türü hasarlar gerçekleşebilmektedir. 
Ülkemizde 1999 Marmara Depremi sonrasında sıvılaşmaya bağlı gözlenmiş hasarlar (Mollamahmutoglu vd. 2003; Bray vd. 2004; Cetin vd. 2004a; Bray ve Dashti 2010), sıvılaşma tehlikesi konusundaki duyarlılığın gelişmesi gerekliliğini ortaya çıkarmıştır. Depremler sırasında zeminlerin sıvılaşma hassasiyetinin belirlenmesi ve olası etkilerinin kaldırılması veya kısmen azaltılması konuları günümüzde oldukça önemli bir hale gelmiştir.

Zeminlerin sıvılaşma hassasiyetini belirlemek için yaygın olarak kullanılan gerilme esaslı yöntemlerde, depremden kaynaklanan tekrarlı kayma gerilmeleri ile zeminin sıvılaşmaya karşı tekrarlı kayma direnci karşılaştııılmakta ve zeminin sıvılaşmaya karşı güvenliği değerlendirilmektedir. İlk olarak Seed ve Idriss (1971) tarafından önerilen bu yaklaşım özellikle 2000'li yıllarında başlarındaki çalışmalar sonunda büyük bir gelişim sağlamıştır (Youd vd. 2001; Cetin vd. 2004b; Idriss ve Boulanger 2008; Idriss ve Boulanger 2010; Boulanger ve Idriss 2014). Günümüzde dünyanın pek çok ülkesinde olduğu gibi Türkiye'de de yaygın olarak kullanılan ve 2019 yılında yürürlüğe girecek olan yeni Türkiye Bina Deprem Yönetmeliği (TBDY)'nde de sıvılaşma analizleri için önerilen bir yöntem olmuştur.

Zeminlerin sıvılaşma mekanizmasının çok sayıda parametreden etkilenmesinden dolayı, zeminlerin sıvılaşma hassasiyeti laboratuvar ve arazi deneylerine dayalı olarak belirlenmeye çalşsılmaktadır. Bu deneylerin başında ise ülkemizde zemin incelemelerinde de yaygın olarak kullanılan standart penetrasyon deneyi (SPT) gelmektedir. SPT sonuçları, özellikle granüler zeminlerin sıkılık ve kayma direnci özelliklerini tahmin etmenin yanı sıra sıvılaşma analizlerinde de sıklıkla kullanılmaktadır. SPT'ye dayalı gerilme esaslı sıvılaşma analizlerinde; depremin büyüklüğü, deprem sırasında zemin yüzeyinde oluşan pik yatay yer ivmesi, zemin özellikleri, dane dağılımı, arazi koşulları, yeraltı su seviyesi, arazi çalışmaları sırasında kullanılan ekipman özellikleri ve standart penetrasyon direnci (SPT-N) gibi çok sayıda parametre ile laboratuvar ve arazi gözlemlerine dayalı olarak geliştirilmiş birçok ampirik ifade kullanılmaktadır. Analizlerde kullanılan parametrelerin ve ampirik ifadelerin sayısının fazlalığı, yönetmeliklerimize yeni girmiş olan bu analizlerin konunun ehli olmayan kişilerce gerçekleştirmesi halinde, uygulamadaki zemin etüt raporlarında sıvılaşma riski ile ilgili değerlendirmelerin önemli hatalar içermesine sebep olabilmektedir.

Bu nedenle, bu çalışma kapsamında, zeminlerin sıvılaşma analizlerini hatasız ve pratikte kullanılabilir kılmak için Türkiye koşullarındaki SPT’ne dayalı sıvılaşmaya karşı güvenlik sayılarının belirlenebildiği grafikler hazırlanmıştır. Seçilen tipik bir arazi modeli için yeni Türkiye Bina Deprem Yönetmeliği (TBDY)'ne dayalı olarak farklı ince dane oranları ( $\mathrm{FC}=\% 5,15,25,35)$, SPT-N değerleri $(\mathrm{N}=5,10, \ldots, 30,35)$, yeraltı su seviyeleri $\left(\mathrm{h}_{\mathrm{w}}=0,2, \ldots, 12,14 \mathrm{~m}\right)$ ve farklı derinliklere $(\mathrm{z}=1.8,3.3, \ldots, 18.3,19.8 \mathrm{~m})$ sahip toplam 2912 durum için sıvılaşma analizleri gerçekleştirilmiştir. Tüm analiz sonuçları kullanılarak, kum zeminlerin sıvılaşmaya karşı güvenlik sayısını veren grafikler hazırlanmış ve farklı deprem büyüklükleri ve pik yatay yer ivmesi değerleri için de sonuç verecek şekilde düzeltme ifadeleri önerilmiş̧ir. Ayrıca, sıvılaşma potansiyeli varlığının tespit edildiği zeminlerde yaygın olarak kullanılan yöntemlerden birisi olan zeminin vibro-taş kolon, derin karıştırma ve jetgrout kolonu gibi elemanların teşkili ile iyileştirilmesi durumunda literatürde yer alan iki farklı yaklaşıma göre, kolonların rijitliği ve yerleşim sıklığı gibi tasarım parametrelerinin belirlenmesini sağlayan kartlar verilmiştir.

\section{SPT'ye Dayalı Sıvılaşma Analizi}

Zeminlerin gerilme esaslı sıvılaşma hassasiyetinin değerlendirilmesi için basitleştirilmiş prosedür geliştirme çalışmaları ilk olarak Seed ve Idriss (1971) tarafindan gerçekleştirilmiştir. Sıvılaşma analizi açısından temel teşkil eden bu çalışma zamanla güncellenerek dünyanın pek çok ülkesinde olduğu gibi Türkiye'de de kumların sıvılaşma hassasiyetini belirlemek için yaygın olarak kullanılan bir yöntem haline gelmiş ve yeni TBDY'nde de yerini almıştır. Bu yöntemde, deprem sırasında zeminin sıvılaşmaya karşı güvenliği, zeminin tekrarlı direnç oranının (CRR), depremden kaynaklanan tekrarlı gerilme oranı (CSR) ile kıyaslanmaktadır. Deprem sırasında oluşan tekrarlı gerilme oranı, Seed ve Idriss (1971) tarafindan Denklem 1'deki gibi tanımlanmıştır:

$$
C S R=0.65 \times \frac{P G A}{g} \times \frac{\sigma_{v}}{\sigma_{v}} \times r_{d}
$$

Burada; PGA, deprem sırasındaki zemin yüzeyindeki pik yatay yer ivmesi olup inşaat alanındaki beklenen değeri sismik tehlike analizlerine dayalı olarak belirlenmektedir. Bu değer, yeni TBDY'nde sismik tehlike haritasından inşaat alanının koordinatları ve tasarımda seçilen tekerrür aralığına göre elde edilebilmektedir. g, yer çekimi ivmesi; $\sigma_{\mathrm{v}}$ ve $\sigma_{\mathrm{v}}{ }_{\mathrm{v}}$, sırasıyla, sıvılaşma değerlendirmesinin yapıldığı derinlikteki (z) toplam ve efektif gerilme; $r_{d}$ ise gerilme azalım katsayısı olup Denklem 2'de verilen derinliğe bağlı ifadelerden belirlenmektedir (Liao ve Whitman 1986).

$r_{d}=\left\{\begin{array}{lc}1.0-0.00765 z & z \leq 9.15 \mathrm{~m} \\ 1.174-0.0267 z & 9.15<z \leq 23 \mathrm{~m}\end{array}\right.$

Zeminlerin tekrarlı direnç oranının (CRR) belirlenmesinin en makul yöntemi, araziden alınan örselenmemiş numuneler üzerinde tekrarlı üç eksenli, tekrarlı basit kesme, tekrarlı burulmalı kesme deneyleri gibi laboratuvar deneyleri gerçekleştirmektir. 
Ancak, numune alımı sırasındaki örselenmeler, cihaz gereksinimleri, zaman ve maliyet gibi faktörlerden dolayı çok özel mühendislik yapıları dışında tekrarlı direnç oranı (CRR) arazi deneylerine dayalı olarak tahmin edilmeye çalışılmaktadır. Türkiye'de gerçekleştirilen uygulamalarda ise özellikle SPT'ye dayalı sıvılaşma analizlerinin daha çok tercih edilen bir yöntem olduğu görülmektedir.

Sondaj sırasında yapılan standart penetrasyon deneyinde arazide ölçülen darbe sayısı (SPT-N); örtü basıncı, enerji oranı, sondaj kuyusu çapı, tij boyu ve numune alıcı türü gibi birçok faktöre bağlıdır. Bu nedenle, SPT'ye dayalı hesaplamalarda kullanılacak olan SPT-N değerlerinin öncelikle düzeltilmesi gerekmektedir. $100 \mathrm{kPa}$ 'lık örtü basıncı ve \%60 enerji verimliliği için düzeltilmiş SPT-N değerleri, $\left(\mathrm{N}_{1}\right)_{60}$, Denklem 3'den elde edilebilir. Yeni TBDY'nde farkl1 SPT ekipmanları için önerilen düzeltme faktörleri Tablo 1'de verilmiştir.

$\left(N_{1}\right)_{60}=N \cdot C_{N} \cdot C_{E} \cdot C_{B} \cdot C_{R} \cdot C_{S}$

İnce dane oranı $\% 5$ 'den az olan temiz kumlar $(\mathrm{FC} \leq \% 5)$ için $\mathrm{M}_{\mathrm{w}}=7.5$ büyüklüğündeki depremler için sıvılaşmanın gerçekleştiği ve gözlenmediği bölgeleri ayıran eğri, Youd vd. (2001) tarafından temiz kum eğrisi olarak tanımlanmakta ve bu durum için tekrarlı direnç oranı $\left(\mathrm{CRR}_{7.5}\right)$ Denklem 4'deki gibi formüle edilmektedir:

$C R R_{7.5}=\frac{1}{34-\left(N_{1}\right)_{60, c s}}+\frac{\left(N_{1}\right)_{60, c s}}{135}+\frac{50}{\left[10 .\left(N_{1}\right)_{60, c s}+45\right]^{2}}-\frac{1}{200}$

Kum içerisindeki ince dane miktarı artışı zeminin tekrarlı kayma direncini artırmaktadır. 100 kPa'lık örtü basıncı ve 7.5 büyüklüğündeki deprem için, ince dane oranının $\% 5$ 'den fazla olması durumunda düzeltilmiş $\left(\mathrm{N}_{1}\right)_{60}$ değerleri Denklem 5 kullanılarak eşdeğer temiz kum değerlerine $\left(\mathrm{N}_{1}\right)_{60, \text { cs }}$ dönüştürülmektedir. Burada $\alpha$ ve $\beta$ ifadeleri ince dane oranına bağlı olarak Denklem 6 ve 7'de verilmiştir.

$\left(N_{1}\right)_{60, c s}=\alpha+\beta\left(N_{1}\right)_{60}$

$\alpha=\left[\begin{array}{ll}0 & ; F C \leq \% 5 \\ \exp \left[1.76-\left(190 / F C^{2}\right)\right] & ; \% 5<F C<\% 35 \\ 5 & ; F C \geq \% 35\end{array}\right]$

$\beta=\left[\begin{array}{ll}1 & ; F C \leq \% 5 \\ 0.99+\left(F C^{1.5} / 1000\right) & ; \% 5<F C<\% 35 \\ 1.2 & ; F C \geq \% 35\end{array}\right]$

Deprem büyüklüğünün $\mathrm{M}_{\mathrm{w}}=7.5$ 'den farklı olması, örtü basıncının $100 \mathrm{kPa}$ 'dan fazla olması ve zeminin deprem öncesinde başlangıç statik kayma gerilmelerine maruz kalması durumları için, tekrarlı direnç oranı Denklem 8'deki gibi genelleştirilebilir.

Tablo 1: SPT düzeltme faktörleri (TBDY 2018)

\begin{tabular}{ccc}
\hline Düzeltme Faktörü & Ekipman Değişkeni & Düzeltme Değeri \\
\hline Örtü basıncı & - & $\left(95.76 / \sigma_{\mathrm{v}}\right)^{0.5} \leq 1.7$ \\
$\left(\mathrm{C}_{\mathrm{N}}\right)$ & Halkalı tokmak & $0.45-1.00$ \\
\hline \multirow{2}{*}{ Enerji oranı } & Güvenli tokmak & $0.60-1.17$ \\
$\left(\mathrm{C}_{\mathrm{E}}\right)$ & Otomatik darbeli tokmak & $0.90-1.60$ \\
\hline \multirow{2}{*}{ Sondaj delgi çapı } & $65-115 \mathrm{~mm}$ & 1.0 \\
$\left(\mathrm{C}_{\mathrm{B}}\right)$ & $150 \mathrm{~mm}$ & 1.05 \\
& $200 \mathrm{~mm}$ & 1.15 \\
\hline \multirow{2}{*}{ Tij boyu } & $3-4 \mathrm{~m}$ & 0.75 \\
$\left(\mathrm{C}_{\mathrm{R}}\right)$ & $4-6 \mathrm{~m}$ & 0.85 \\
& $6-10 \mathrm{~m}$ & 0.95 \\
& $10-30 \mathrm{~m}$ & 1.0 \\
\hline Numune alıcı tipi & Standart numune alıcı & 1.0 \\
$\left(\mathrm{C}_{\mathrm{S}}\right)$ & İc tüpü olmayan numune alıcı & $1.1-1.3$ \\
\hline
\end{tabular}


$C R R_{M, \sigma_{v}^{\prime}}=C R R_{7.5} \times C_{M} \times K_{\sigma} \times K_{S}$

Burada; $\mathrm{C}_{\mathrm{M}}$, Denklem 9'da tanımlanan deprem magnitüdü düzeltme faktörüdür. $\mathrm{K}_{\sigma}$ örtü basıncı düzeltme faktörü olup Denklem 10'da verilmiştir. Denklem 10'daki f ifadesi zeminin rölatif sıkılığına bağlı 0.6 ile 0.8 arasında bir değerdir (Youd vd. 2001). $\mathrm{K}_{\mathrm{S}}$ düzeltme faktörü ise başlangıç statik kayma gerilmesinin etkisini hesaba katan bir parametre olup günümüzde genellikle ihmal edilmektedir.

$$
\begin{aligned}
& C_{M}=\left(M_{w} / 7.5\right)^{-2.56} \\
& K_{\sigma}=\left(\sigma_{v}^{\prime} / 100\right)^{f-1}
\end{aligned}
$$

Sıvılaşmaya karşı güvenlik sayısı ise Denklem 1 ve 8'de tanımlanan gerilme oranlarına bağlı olarak Denklem 11 'deki gibi tanımlanmaktadır. Literatürde güvenlik sayısının genellikle 1.1'in altında olması durumu, zeminin sıvılaşma hassasiyetinin varlığını işaret etmekte olup yeni TBDY'nde de bu değer aynen kullanılmıştır.

$$
F S=\frac{C R R_{M, \sigma_{v}^{\prime}}}{C S R}
$$

\section{Analizler ve Bulguların Tartışılması}

$\mathrm{Bu}$ çalışma kapsamında yeni TBDY'nde verilen SPT’ye dayalı sıvılaşma analizleri için güvenlik sayılarının belirlenmesini sağlayacak olan grafiklerin hazırlanması için Şekil 1'deki arazi modeli kullanılmıştır. Zemin özellikleri için Tablo 2'de verilen gerçekçi veri aralıkları ile analizler gerçekleştirilmiştir. Tüm analizlerde zemin tabakalarının yeraltı su seviyesi üzerindeki tabii birim hacim ağırlıkları $17 \mathrm{kN} / \mathrm{m}^{3}$, yeraltı su seviyesi altındaki doygun birim hacim ağırlıkları ise $18 \mathrm{kN} / \mathrm{m}^{3}$ olarak kabul edilmiştir. Analizlerin gerçekleştirileceği derinlikler (z), standart penetrasyon deneyi sırasındaki arazide ölçülen darbe sayıları (SPT-N), ince dane oranları (FC) ve yeraltı su seviyesi derinlikleri $\left(\mathrm{h}_{\mathrm{w}}\right)$ değişken olarak seçilmiştir. Değiş̧kenlerin aralıkları Tablo 2'de verildiği üzere, SPT-N için 5 - 35, FC için \% 5 - 35, YASS için 0 - 14 m, z için 0 - 19.8 m olmak üzere toplam 2912 sıvılaşma analizi yapılmıştır. Analizlerde, standart penetrasyon deneyi düzeltme faktörlerinin seçiminde ise Türkiye'de yaygın olarak kullanılan ekipmanlara ait değerler kullanılmıştır. Türkiye'deki halkalı tokmak kullanımı için Sivrikaya ve Toğrol (2009) tarafından önerilen enerji oranı düzeltme faktörü, $\mathrm{C}_{\mathrm{E}}=0.75$; sondaj kuyusu çapı düzeltme faktörü, $\mathrm{C}_{\mathrm{B}}=1.0$; numune alıcı düzeltme faktörü ise $\mathrm{C}_{\mathrm{S}}=1.0$ olarak alınmıştır. Örtü basıncı düzeltme faktörü $\left(C_{N}\right)$ ve tij boyu düzeltme faktörü $\left(C_{R}\right)$ ise analizin gerçekleştirileceği derinliğine bağlı olarak Tablo 1'e göre belirlenmiştir. Standart penetrasyon deney seviyeleri uygulamadakine benzer şekilde her $1.5 \mathrm{~m}$ 'de bir ve maksimum 20 m derinliğe kadar toplam 13 nokta olarak seçilmiştir. Analizlerin gerçekleştirildiği derinlikler SPT$\mathrm{N}$ değerlerinin ölçüldüğü ortalama derinliği temsil etmek için $\mathrm{z}=1.8 ; 3.3 ; 4.8 ; \ldots ; 19.8 \mathrm{~m}$ olarak alınmıştır.

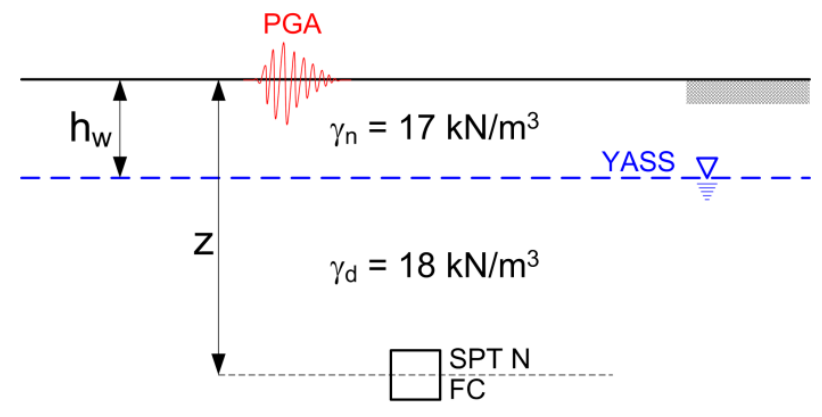

$\mathrm{z}_{\max }=20 \mathrm{~m}$

Şekil 1: Analizlerde kullanılan arazi modeli 
Tablo 2: Analizlerde kullanılan değişkenler ve değerleri

\begin{tabular}{ll}
\hline Değişken & Değerler \\
\hline Yeraltı su seviyesi, $\mathrm{h}_{\mathrm{w}}(\mathrm{m})$ & $0.0 ; 2.0 ; 4.0 ; 6.0 ; 8.0 ; 10.0 ; 12.0 ; 14.0$ \\
\hline \multirow{2}{*}{ Derinlik, $\mathrm{z}(\mathrm{m})$} & $1.8 ; 3.3 ; 4.8 ; 6.3 ; 7.8 ; 9.3 ; 10.8 ;$ \\
& $12.3 ; 13.8 ; 15.3 ; 16.8 ; 18.3 ; 19.8$ \\
\hline SPT vuruş sayısı, SPT-N & $5 ; 10 ; 15 ; 20 ; 25 ; 30 ; 35$ \\
\hline İnce dane yüzdesi, FC $(\%)$ & $5 ; 15 ; 25 ; 35$ \\
\hline
\end{tabular}

SPT'ye dayalı sıvılaşma analizlerinde depremin karakteristikleri ile ilgili etkiler; depremin büyüklüğü ve deprem sırasındaki zemin yüzeyindeki pik yatay yer ivmesi olarak iki parametre ile ifade edilmektedir. Pik yatay yer ivmesi, inşaat alanının faya olan uzaklığı, depremin büyüklüğü, zemin özellikleri ve fay özelliklerine bağlı olarak yeni TBDY'nde verilen sismik tehlike haritaları sayesinde farklı tekerrür aralıkları için kolaylıkla belirlenebilir hale gelmiştir. Bu çalışmadaki sıvılaşma analizleri, $\mathrm{M}_{\mathrm{w}}=7.5$ büyüklüğündeki ve pik yatay yer ivmesi, PGA = 1.0g olan deprem için

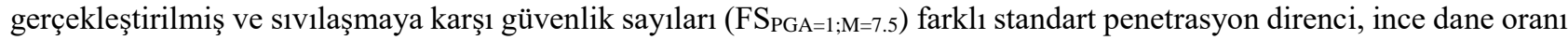
ve yeraltı su seviyeleri için derinliğe bağlı olarak hesaplanmıştır. Yeraltı su seviyesinin, $\mathrm{h}_{\mathrm{w}}=0$ m'den 14 m'ye kadar 2 m'lik artışları için güvenlik sayılarının SPT-N, ince dane oranı ve derinlikle değişimleri Şekil 2-9'da görülmektedir. Bu grafiklerin her biri ince dane içeriklerinin $\% 5, \% 15, \% 25$ ve $\% 35$ olması durumları (sırasıly şekillerde a, b, c, d) ve ham standart penetrasyon darbe sayılarının SPT-N = 5 ile 35 arasında değiştiği 7 farklı durum için ayrı ayrı verilmiştir.

Grafiklerde, sıvılaşma değerlendirmesinin yapıldığı derinlikte SPT-N değerine karşılık gelen bir nokta bulunmuyorsa, bu durum ilgili derinlikte sıvılaşma potansiyelinin olmadığı anlamına gelmektedir. Örneğin, Şekil 2a'da SPT-N = 35 için $\mathrm{z}=9.3$ m'nin üzerindeki derinliklerde bir değerin bulunmaması, bu YASS için $9.3 \mathrm{~m}$ seviyesine kadar SPT-N $=35$ olan kumlarda sıvılaşmanın oluşmayacağını ifade etmektedir. Benzer şekilde, YASS üzerindeki derinliklerde de zeminin sıvılaşmayacağı grafikler üzerinde gösterilmektedir. Grafikler incelendiğinde, aynı yeraltı su seviyesi ve ince dane oranı değerleri için SPT-N'in artışı ile sıvılaşmaya karşı güvenlik sayılarının önemli ölçüde arttığı görülmektedir. SPT-N değerinin 35 olması durumunda dahi düzeltme faktörlerinin etkisiyle özellikle derinliğin fazla olduğu seviyelerde sıvılaşma durumları söz konusu olabilmektedir. Bu durum, $\left(\mathrm{N}_{1}\right)_{60}$ '’n 30'dan büyük olduğu durumlar için sıvılaşma gözlenmeyeceği algısının ham SPT-N ile karıştırılmaması gerektiğini göstermektedir. Grafiklerdeki önemli tespitlerden birisi de, YASS'nin yüzeye yakın olduğu durumlarda, ince dane oranı etkisinin özellikle de yüksek SPT-N değerleri için oldukça önemli düzeyde olduğu ve bazı durumlarda ise zeminin sıvılaşma potansiyelini tamamen ortadan kaldırabilecek seviyelere ulaşabildiğidir. YASS'nin derinliği arttıkça ince dane oranındaki artış güvenlik sayısını daha sınırlı ölçüde artırmaktadir.

Şekil 2-9'da verilen bu grafikler, seçilen tipik arazi koşullarına dayalı olarak hazırlanmış ve kullanımı oldukça kolay olan grafiklerdir. Örneğin, yeraltı su seviyesi zemin yüzeyinden $\mathrm{h}_{\mathrm{w}}=2 \mathrm{~m}$ olan bir arazide, $\mathrm{z}=7.50-7.95 \mathrm{~m}$ seviyesinde gerçekleştirilen SPT sonunda ham SPT-N'nin 20, ince dane oranının ise \%15 olduğu kumlu bir zeminde 7.5 büyüklüğünde ve $1.0 \mathrm{~g}$ 'lik pik yatay yer ivmesi oluşturan bir depremde sıvılaşmaya karşı güvenlik sayısı Şekil 3.b'den yaklaşık 0.196 olarak kolaylıkla belirlenebilmektedir. Arazideki gerçek bir durum için SPT-N değeri, ince dane oranı (FC) ve yeraltı su seviyesinin $\left(h_{w}\right)$ değerlerinin grafiklerde bulunmaması halinde, Şekil 2-9'da verilen grafiklerden analizin gerçekleştirileceği ilgili derinlikteki arazi değerlerine benzer nitelikte olan en yakın değerlere ait eğriler kullanılarak ilgili noktadaki zeminin sıvılaşmaya karşı güvenlik sayısı interpolasyon yöntemi ile hesaplanabilmektedir.

Öte yandan, gözden kaçırılmaması gereken önemli bir nokta, bu grafiklerin $1.0 \mathrm{~g}$ 'lik pik yatay yer ivmesi ve $\mathrm{M}_{\mathrm{w}}=7.5$ büyüklüğündeki deprem için gerçekleştirildiği ve farklı deprem parametreleri için bu grafiklerden elde edilen güvenlik sayılarının düzeltilmesi gerektiğidir. Bir deprem senaryosu için belirlenen pik yatay yer ivmesi (PGA) ve deprem büyüklüğü $\left(\mathrm{M}_{\mathrm{w}}\right)$ için Şekil 2-9'daki grafiklerden elde edilen güvenlik sayıları ( $\left.\mathrm{FS}_{\mathrm{PGA}=1 ; \mathrm{M}=7.5}\right)$ Denklem 12'ye göre düzeltilerek ilgili arazideki deprem parametrelerine ait güvenlik sayısı ( FS $\left._{\mathrm{PGA}, \mathrm{M}}\right)$ kolaylıkla belirlenebilmektedir. Denklem 12'de PGA, g cinsindendir.

$$
F S_{P G A, M}=F S_{P G A=1, M=7.5} \times \frac{1.0 g}{P G A} \times\left(\frac{7.5}{M_{w}}\right)^{2.56}
$$



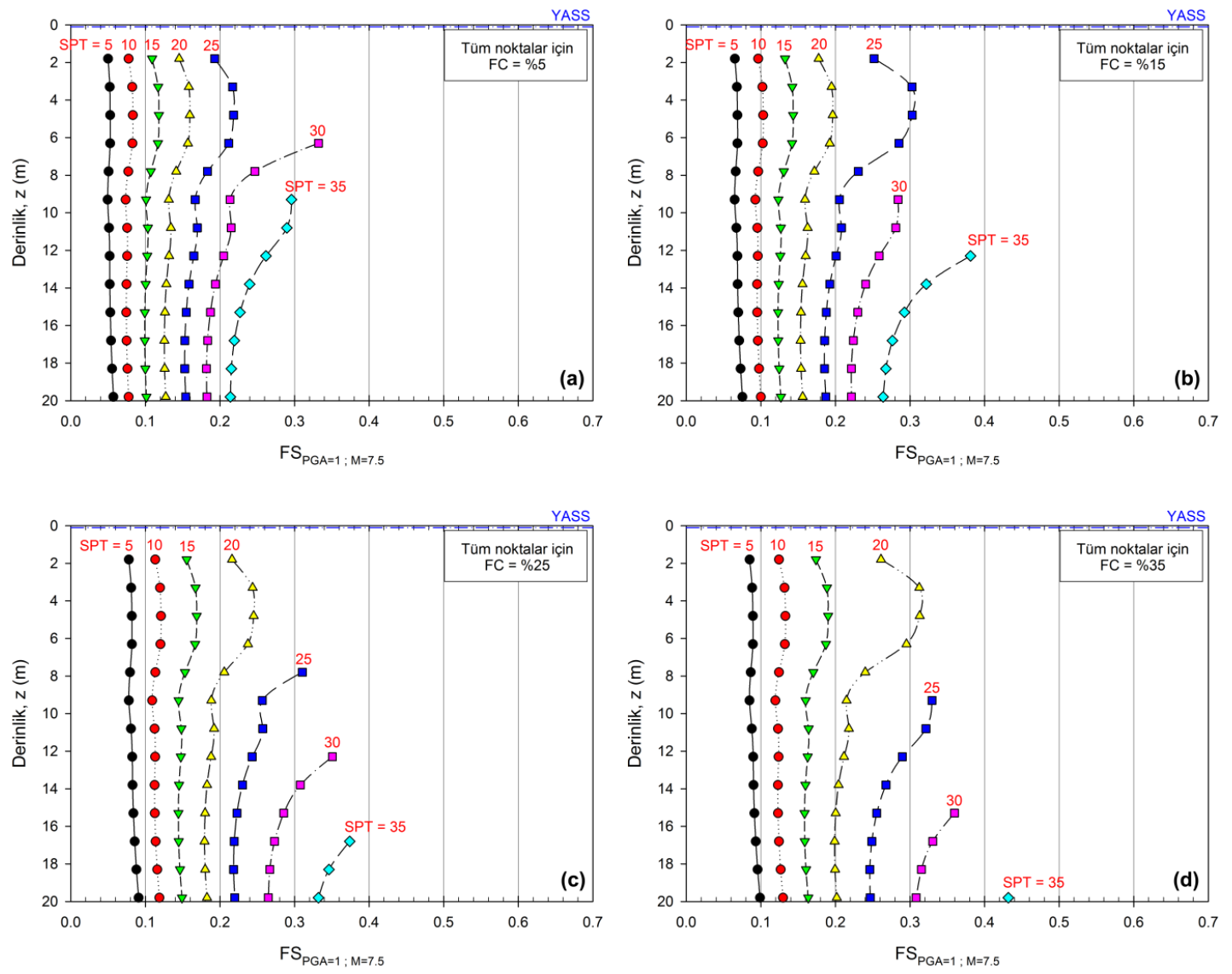

Şekil 2: Yeraltı su seviyesi, $h_{w}=0 \mathrm{~m}$ için güvenlik sayıları (FS $S_{P A=1 ; M=7.5)}$
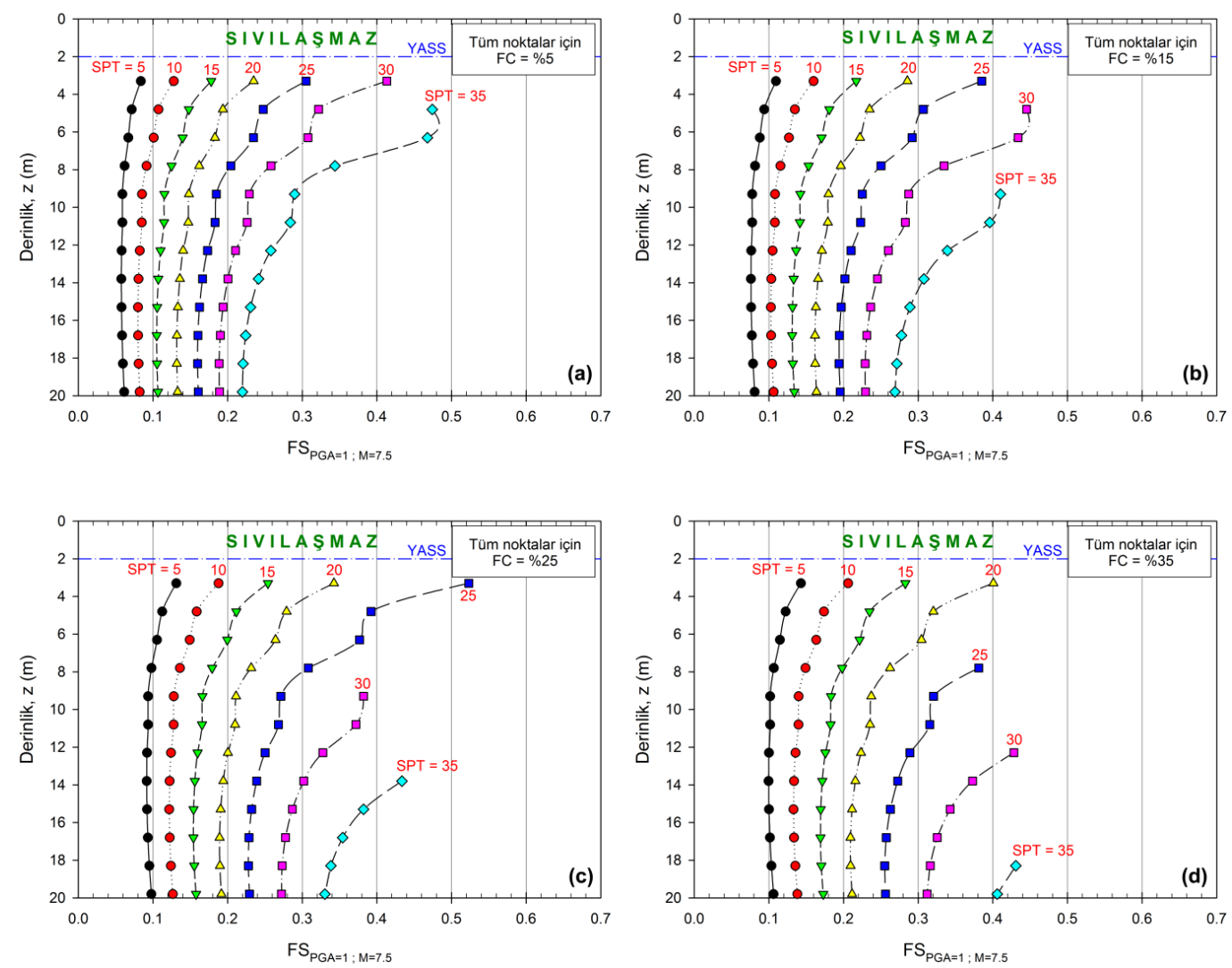

Şekil 3: Yeraltı su seviyesi, $h_{w}=2 m$ için güvenlik sayıları (FS $\left.P G A=1 ; M=7.5\right)$ 

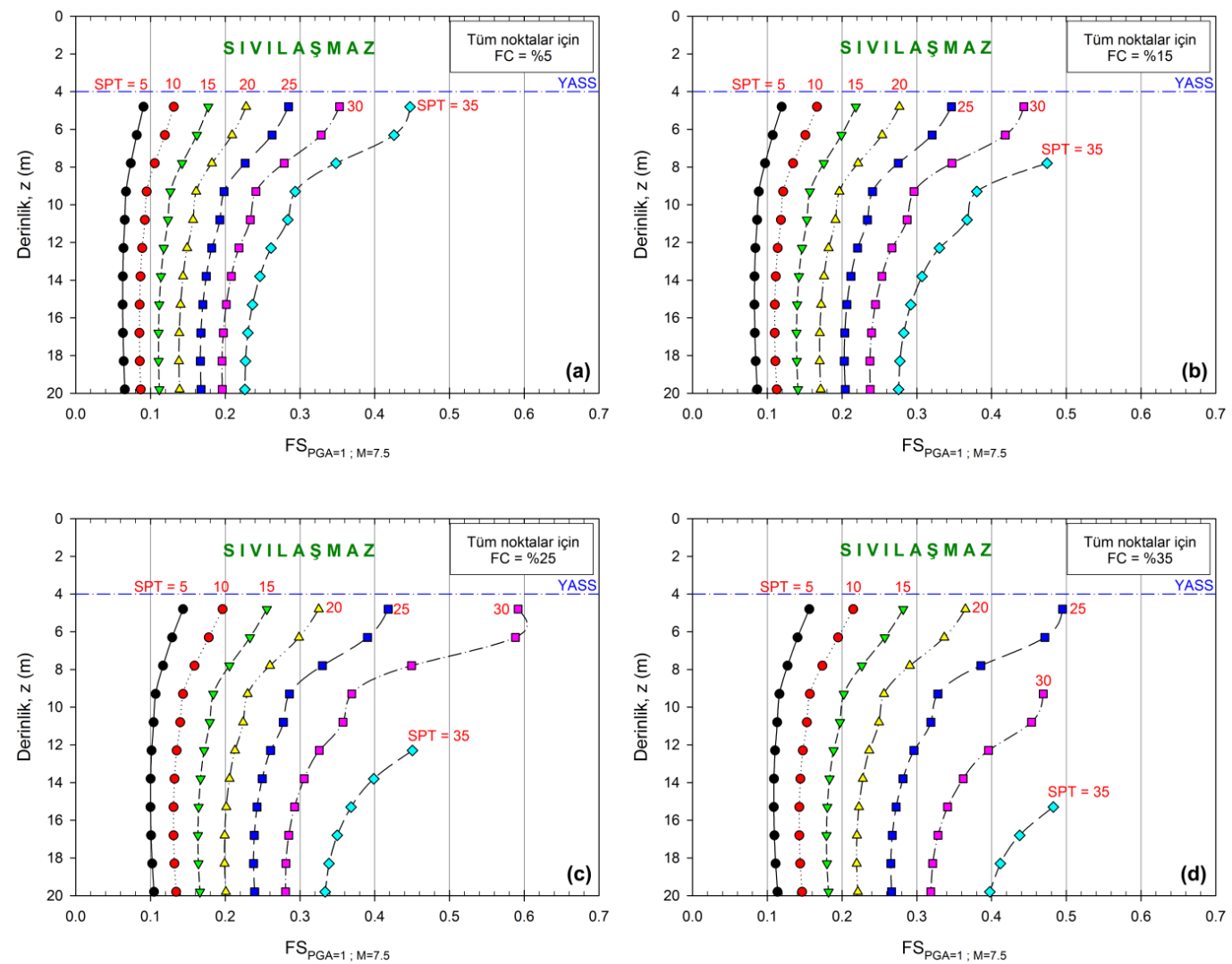

Şekil 4:Yeraltı su seviyesi, $h_{w}=4 m$ için güvenlik sayıları (FSPGA=1;M=7.5)
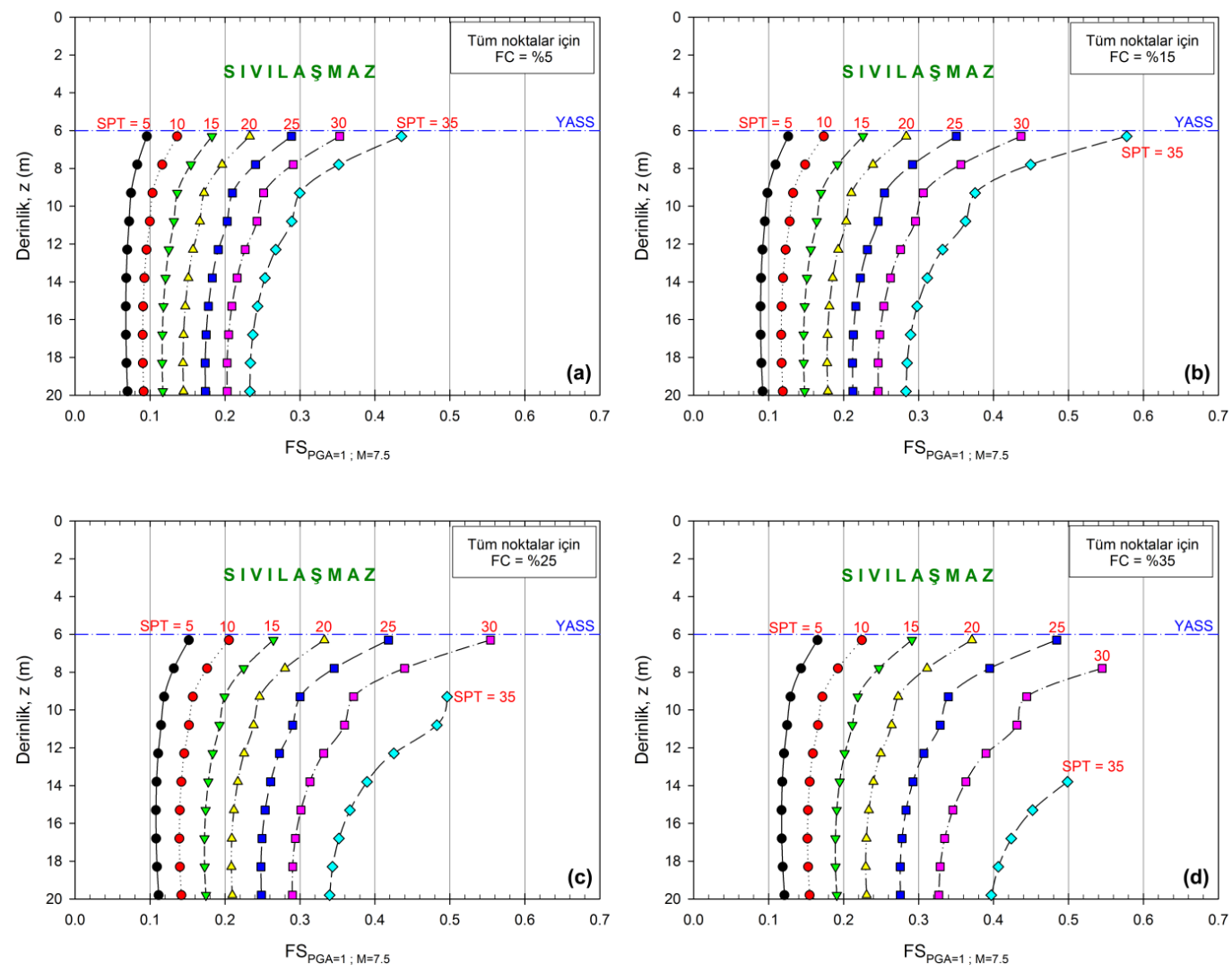

Şekil 5: Yeraltı su seviyesi, $h_{w}=6 m$ için güvenlik sayıları (FSPG=1;M=7.5) 

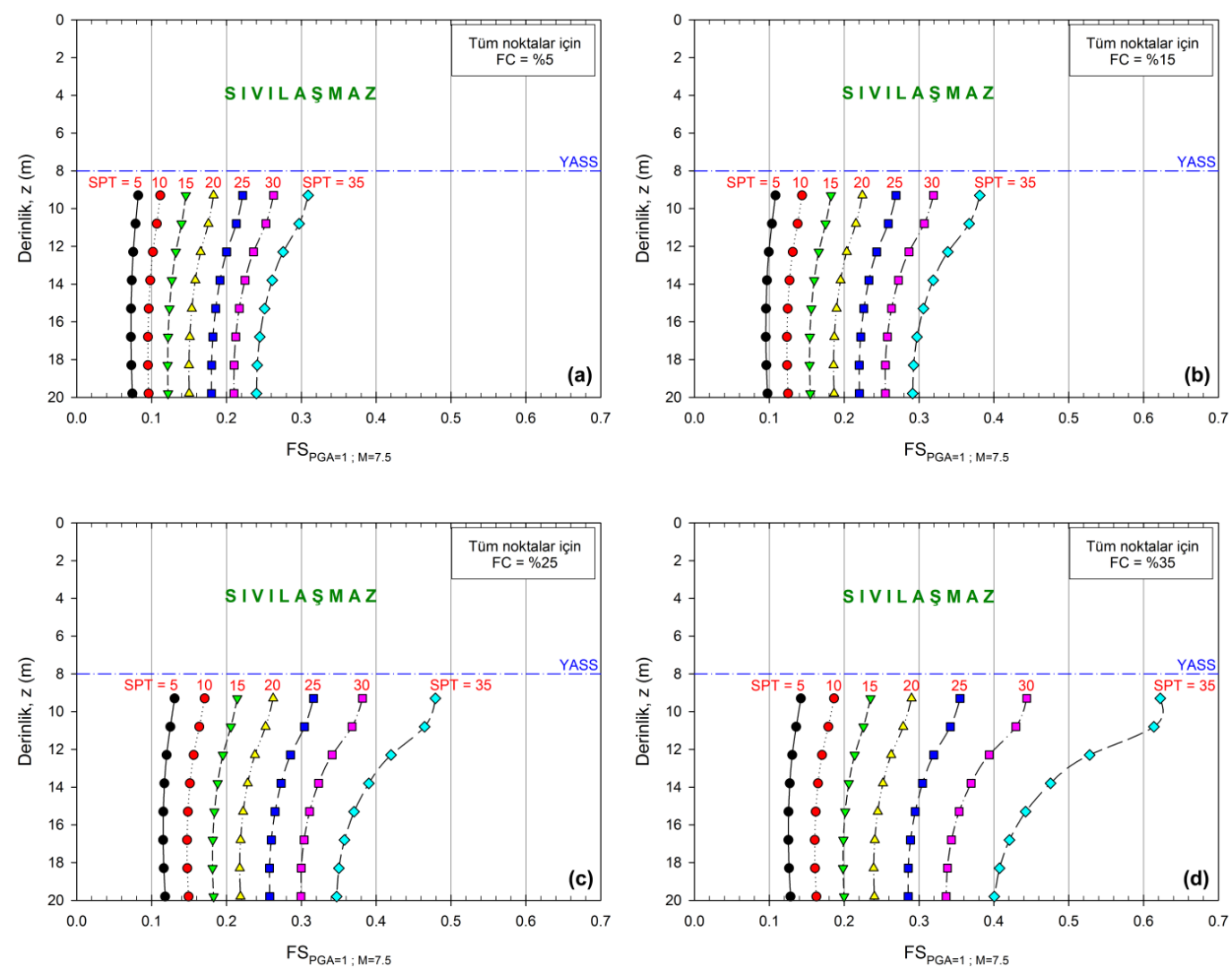

Şekil 6: Yeraltı su seviyesi, $h_{w}=8 m$ için güvenlik sayıları (FSPGA=1;M=7.5)
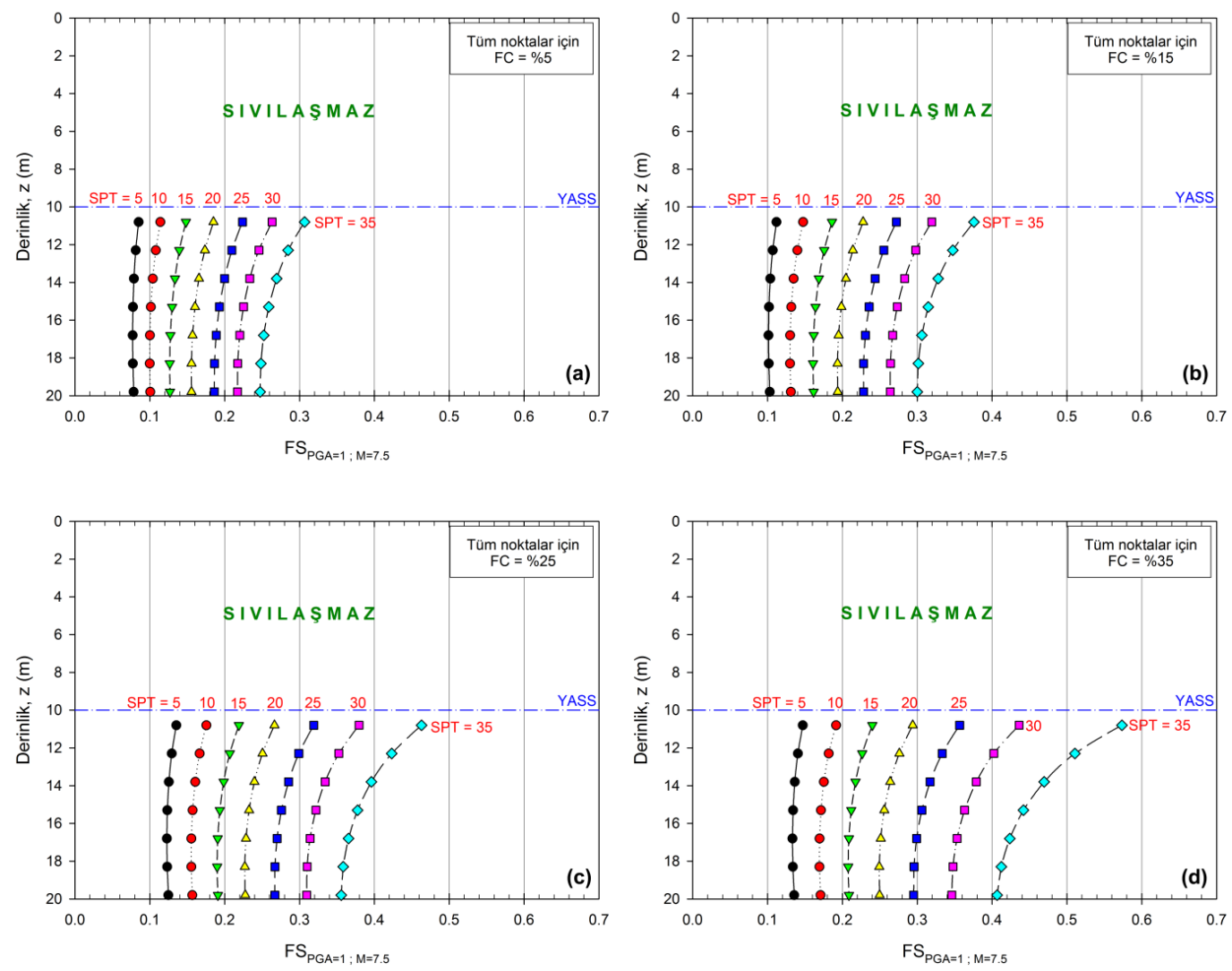

Şekil 7: Yeraltı su seviyesi, $h_{w}=10 m$ için güvenlik sayıları (FSPGA=1;M=7.5) 

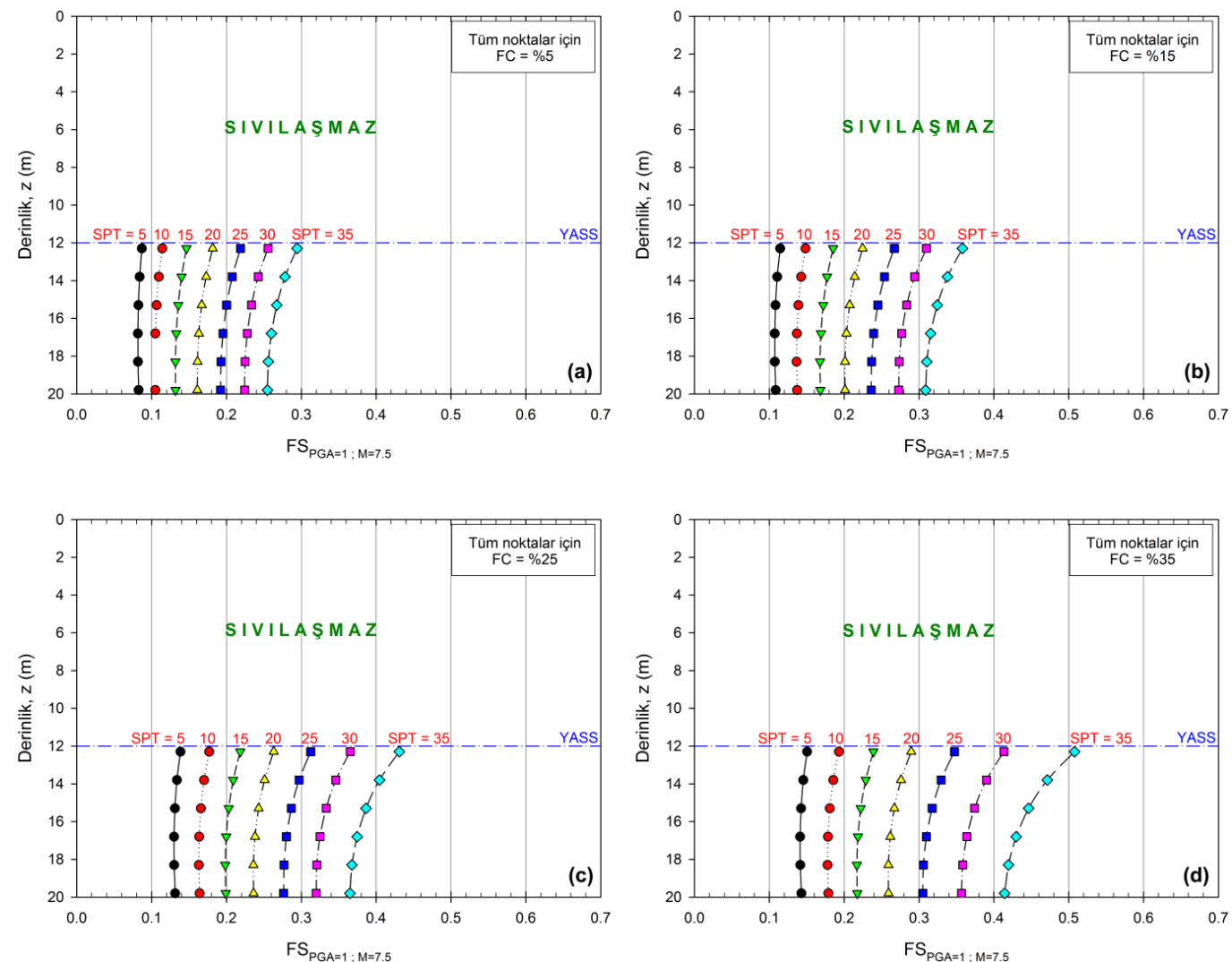

Şekil 8: Yeraltı su seviyesi, $h_{w}=12 m$ için güvenlik sayıları (FS $\left.P G A=1 ; M=7.5\right)$
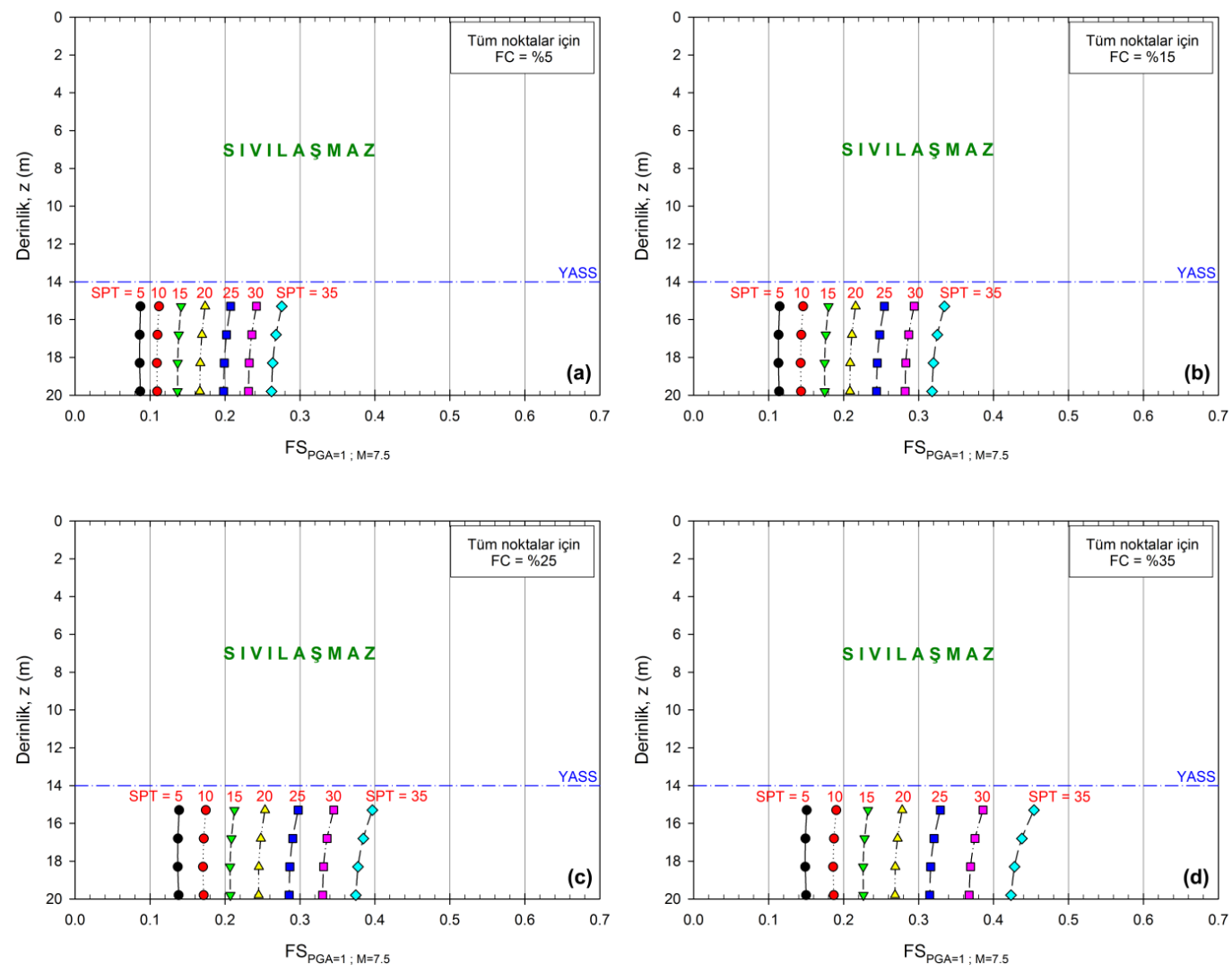

Şekil 9: Yeraltı su seviyesi, $h_{w}=14 m$ için güvenlik sayıları (FSPGA=1;M=7.5) 


\section{Sıvılaşmaya Karşı Kolon Teşkili ile Zeminlerin İyileştirilmesi}

Sıvılaşma potansiyeli varlığının tespit edildiği bir arazide sıvılaşma tehlikesinin doğuracağı muhtemel problemlerin etkisini ortadan kaldırmak veya kısmen azaltabilmek için uygulanabilecek zemin iyileştirme yöntemleri dört ana grup altında toplanabilir: Bunlar; deprem sırasında aşırı boşluk suyu basıncı oluşumunu engellemek, zeminin sıkıştırılması, zemin içinde yüksek modüllü kolonların oluşturulması ve zeminin yanal hareketini sınırlayıcı elemanların yerleştirilmesidir (Durgunoğlu 2004). Uygun bir zemin iyileştirme yönteminin seçimi aşamasında, yöntemin arazide uygulanabilirliği, problemin çözümünde etkinliği, maliyeti, gerekli malzemenin temininin kolaylığı ve çevresel etkilere duyarlılığı gibi konular ön plana çıkmaktadır. Bu nedenle, günümüzde zemin sıvılaşmasına karşı en çok tercih edilen iyileştirme yöntemlerinin başında kolon teşkili (vibro-taş kolon, derin karıştırma ve jetgrout gibi), özellikle de jetgrout uygulamasi gelmektedir.

Zeminlerin sıvılaşma potansiyelini ortadan kaldırmak veya azaltmak için kullanılan vibro-taş kolon, derin karıştırma veya jetgrout kolunu gibi elemanların zemin içinde teşkil edilmesi işlemi üçgensel veya dörtgensel olarak sabit aralıklı bir yerleşim şeklinde uygulanmaktadır. Bu iyileştirme yöntemi için deprem sırasında zemin içerisine yerleştirilen kolonlar ve onları çevreleyen zeminde gerçekleşecek olan kayma birim deformasyon seviyesinin aynı olup olmadığının kabulüne dayalı olarak iki yaklaşım bulunmaktadır. Bu yöntemlerden ilki, Baez (1995)'in vibro-taş kolonlar için geliştirdiği ve Özsoy ve Durgunoğlu (2003)'nun yüksek modüllü kolonlar için uyarladığı kayma gerilmelerinin yeniden dağılım (veya birim hücre) yaklaşımıdır. Bu yaklaşımda, Şekil 10'da gösterildiği üzere, deprem sırasında jetgrout kolonları ve onları çevreleyen zeminde gerçekleşecek olan kayma birim deformasyon seviyesinin aynı olacağ $1\left(\gamma_{\mathrm{JG}}=\gamma_{\mathrm{s}}\right)$ kabul edilmektedir. $\mathrm{Bu}$ durumun oluşumu, Denklem 13'de ifade edildiği üzere, her iki elemanda oluşacak kayma gerilmelerinin kayma modülleri ile orantılı olması durumunda mümkün olabilecektir.

$\frac{\tau_{J G}}{G_{J G}}=\frac{\tau_{s}}{G_{s}}$

Burada, $\tau_{\mathrm{JG}}$ ve $\tau_{\mathrm{s}}$, sırasıyla, jetgrout kolonları ve zeminde oluşacak depremden kaynaklanan kayma gerilmeleri; $\mathrm{G}_{\mathrm{JG}}$ ve $\mathrm{G}_{\mathrm{s}}$ ise sırasıyla, jetgrout kolonları ve onları çevreleyen iyileştirilmemiş zeminin kayma modülleridir.

Herhangi bir derinlikte Şekil 11'deki birim eleman içerisindeki depremden kaynaklanan toplam tekrarlı kesme kuvveti; jetgrout kolonları ve onları çevreleyen zemin tarafından karşılanacaktır. Oluşan kayma gerilmelerinin jetgrout kolonuna aktarılacak olan kısmı, Denklem 14'de tanımlanan jetgrout kolonlarının kayma modülü oranı $\left(G_{r}\right)$ ve Denklem 15'de tanımlanan birim hücre içerisindeki jetgrout kolonlarının alan oranına $\left(\mathrm{a}_{\mathrm{r}}\right)$ bağlıdır. Kayma gerilmelerinin kalan kısmı ise jetgrout kolonlarını çevreleyen zemin tarafından karşılanacaktır. Bu yaklaşıma göre, iyileştirme sonrasında deprem sirasında zemine aktarılan kayma gerilmeleri, ortalama tekrarlı kayma gerilmesine oranı, Denklem 16'da tanımlanan kayma gerilmesi azalım faktörü $\left(S_{r}\right)$ oranında azalacaktır. Ozener vd. (2015), jetgrout kolonlarının deprem yükleri sırasında gelişen kayma gerilmelerinin azalmasında önemli rol oynadığı sayısal analizlere dayalı olarak göstermişlerdir.

$$
\begin{aligned}
& G_{r}=G_{J G} / G_{s} \\
& a_{r}=A_{J G} / A \\
& S_{r}=\frac{\tau_{s}}{\tau}=\frac{1}{G_{r}\left[a_{r}+\frac{1}{G_{r}}\left(1-a_{r}\right)\right]}
\end{aligned}
$$

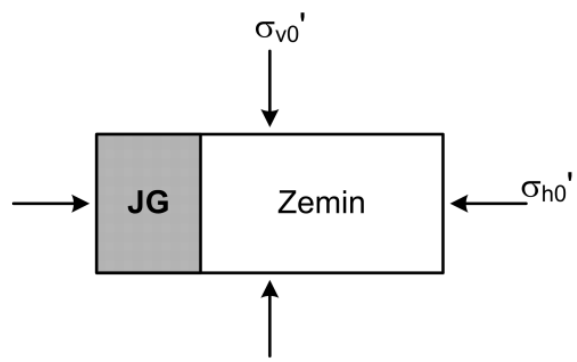

a) Başlangıç Durumu

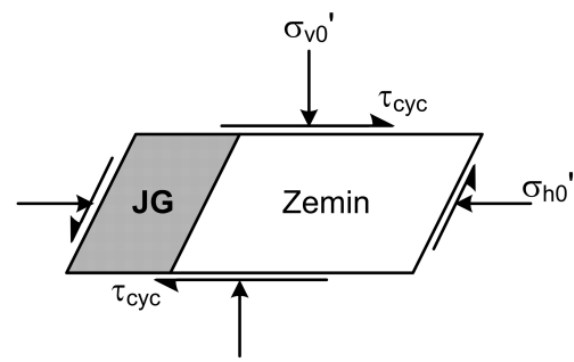

b) Deprem Durumu 


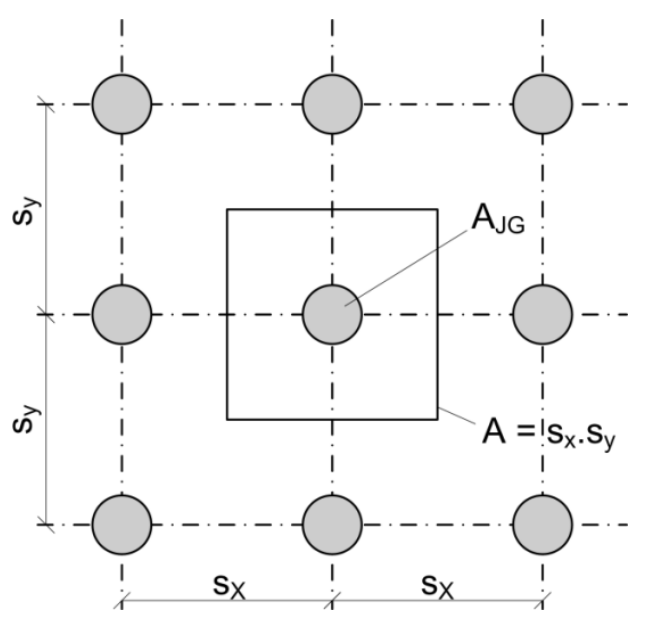

Şekil 11: Birim hücre yaklaşımı

$\mathrm{Bu}$ yaklaşımda, iyileştirme sonrasında zeminin tekrarlı kayma direncinin değişmediği ve zemine etki eden kayma gerilmesinin kayma gerilmesi azalım faktörüne bağlı olarak azaldığı düşünüldüğünden, iyileştirme öncesi sıvılaşmaya karşı güvenlik sayısı, FS $_{\text {önce }}$ olan zemin koşulları için iyileştirme sonrasında güvenlik sayısı Denklem 17'de hesaplanan $\mathrm{FS}_{\text {sonra }}$ değerine yükselecektir.

$F S_{\text {sonra }}=F S_{\text {önce }} / S_{r}$

Zeminin sıvılaşmaya karşı güvenlik katsayısının zemin iyileştirmesi sonrasında hedeflenen bir değere yükseltilebilmesi için kayma modülü oranı $\mathrm{G}_{\mathrm{r}}$ olan jetgrout kolonlarının yerleşim sıklığının Denklem 18'de tanımlanan minimum alan oranına göre belirlenmesi gerekecektir.

$a_{r, \text { gerekli }}=\left(\frac{1}{G_{r}-1}\right) \cdot\left(\frac{F S_{\text {sonra }}}{F S_{\text {önce }}}-1\right)$

$\mathrm{Bu}$ ifadeden elde edilen gerekli olan minimum alan oranı değerinin biri aşması, bu kayma modülü oranına sahip jetgrout kolonlarının zeminin sıvılaşma potansiyelinin ortadan kaldırılması konusunda yetersiz kalacağını göstermektedir. İlerleyen yıllarda gerçekleştirilen araştırmalar, Baez (1995)'in eşdeğer birim deformasyon kabulünden elde edilen kayma gerilmesi azalım faktörünün özellikle yüksek kayma modüllü kolonlar için oldukça yüksek değerler verdiğini göstermiş ve yüksek kayma modüllü kolonlarında depremler sırasında, etrafındaki zemin kadar deformasyona uğramayacağı tespitine dayalı ikinci bir yaklaşım önerilmiştir (Rayamajhi vd. 2014). Rayamajhi vd. (2014) üç boyutlu lineer elastik sonlu elemanlar analiz sonuçlarına dayalı olarak Baez (1995)'in önerdiği Denklem 16'da verilen kayma gerilmesi azalım faktörünü revize ederek, Denklem 19'da verilen modifiye kayma gerilmesi azalım faktörünü $\left(\mathrm{R}_{\mathrm{rd}}\right)$ önermișlerdir.

$$
R_{r d}=\frac{1}{G_{r}\left[a_{r} \gamma_{r} C_{G}+\frac{1}{G_{r}}\left(1-a_{r}\right)\right]}
$$

Burada, $\mathrm{C}_{\mathrm{G}}$, eşdeğer kayma faktörü olup, kesit geometrisine bağlı bir katsayıdır. Rayamajhi vd. (2014), bu faktörü dairesel ayrık kolonlar için 1.0, dikdörtgen derin zemin karıștırma grid yerleşimi için 0.5 olarak tanımlamıștır. $\gamma_{\mathrm{r}}$, ayrık kolonların kayma birim deformasyonunun kolonlar etrafındaki zeminin kayma birim deformasyonuna oranı olarak tanımlanmaktadır. Baez (1995)'in, kolonlar ve zeminin kayma birim deformasyonun uyumlu olduğu kabulünde $\gamma_{\mathrm{r}}=1$ olmaktadır. Rayamajhi vd. (2014) sonlu eleman analiz sonuçlarına göre birim deformasyon oranının büyük ölçüde kayma modülü oranına bağlı olduğunu ifade ederek Denklem 20'yi tanımlamışlardır.

$\gamma_{r}=1.04\left(G_{r}\right)^{-0.65}-0.04$

Her iki yaklaşım birlikte değerlendirildiğinde, sıvılaşmaya karşı kolon teşkili ile zeminin iyileştirilmesi için tasarlanacak kolonların yerleşim sıklığını belirleyen en önemli parametrenin kayma modülü oranı olduğu açıkça görülmektedir. Yeni TBDY’ne göre bir zeminin sıvılaşmaya karşı hassasiyetinin olmadığını söyleyebilmek için güvenlik sayısının en az 1.1 olması istenmektedir. 
İyileştirme öncesinde sıvılaşmaya karşı güvenlik sayısının 1.1'den düşük olduğu zeminlerde, iyileştirme sonrası hedeflenen güvenlik sayısının 1.1'e çıkarılması için seçilmesi gereken kolon yerleşim aralıklarını belirlemek için tasarım kartları oluşturmak mümkündür. Baez (1995)'in eşdeğer birim deformasyon yaklaşımı için farklı kayma modülü oranları ve iyileştirme öncesi sıvılaşmaya karşı güvenlik sayılarına göre uygulanacak olan kolonların minimum alan oranı değerlerini belirlemeye yönelik olarak Şekil 12'deki, benzer şekilde Rayamajhi vd. (2014)'ün kolonlar ve etrafindaki zeminin farklı birim deformasyonlarına uğraması yaklaşımı için de Şekil 13'deki kartlar hazırlanmıştır. Şekil 12a ve Şekil 13a daha çok vibro-taş kolonlar gibi kayma modülü küçük olan kolonlar $\left(G_{r}=2 \sim 10\right)$ için, Şekil 12b ve Şekil 13b ise derin karıştırma ve jetgrout gibi yüksek modüllü kolonlar $\left(G_{r}=15 \sim 150\right)$ için ayrı ayrı oluşturulmuştur. Şekil 13'deki eğrilerin oluşturulması sırasında, Şekil 12'den farklı olarak kayma modülü oranının 75'i aşması durumunda elde edilen alan oranı değerlerinin gerçekçi olmayan değerler vermesi nedeniyle grafiklerde bu eğrilere yer verilmemiştir.

Şekil 12'de eşdeğer deformasyon yaklaşımına göre tasarım yönteminde, iyileştirme öncesindeki belirli bir güvenlik sayısı için iyileştirme kolonların kayma modülünün artışıyla gerekli kolon sıklığını yansıtan alan oranı değerinin büyük ölçüde azalmasının yeterli olacağı görülmektedir. Örneğin, iyileştirme öncesinde güvenlik sayısının 0.3 olduğu zeminler için, kayma modülü oranı 10 olduğunda dahi güvenlik sayısını 1.1'e yükseltebilme için alan oranının 0.3 olması yeterli görülmektedir. Kayma modülü oranının daha da yükselmesi halinde bu değer hızlı bir şekilde 0.1 seviyelerine, yani birim hücre içerisindeki kolon yoğunluğunun \%10'a düşmesi anlamına gelmektedir. Eşdeğer kayma birim deformasyonunun oluşmadığı kabulüne dayalı Şekil 13 incelendiğinde ise, iyileştirme öncesi güvenlik sayısının 0.5 'den daha düşük olduğu durumlarda, seçilen iyileştirme kolonlarının kayma modülü oranı ne olursa olsun iyileştirme sonrası güvenlik sayısının 1.1'e ulaştırılmasının mümkün olmadığı görülmektedir. Ancak, uygulamada jetgroutların deprem performansları bu tespiti doğrular nitelikte değildir. İki yaklaşım arasındaki bu önemli farklılığın özellikle gerçek arazi gözlemleri ve ölçümleri ile doğrulanması gerektiğini açıktır. Fakat bu bilgi birikimlerinin oluşma süreci içerisinde, bu iki yöntemin birlikte düşünülmesi kaçınılmaz görülmektedir. Bu nedenle, iki farklı yaklaşıma göre Şekil 12 ve Şekil 13'de verilen bu kartların, iyileştirme öncesi güvenlik sayılarına göre tasarlanan kolonların rijitliklerine bağlı olarak birim hücre eleman içerisinde olması gereken minimum kolon yoğunluğunun bulunması için kullanımı oldukça pratik olacaktır.
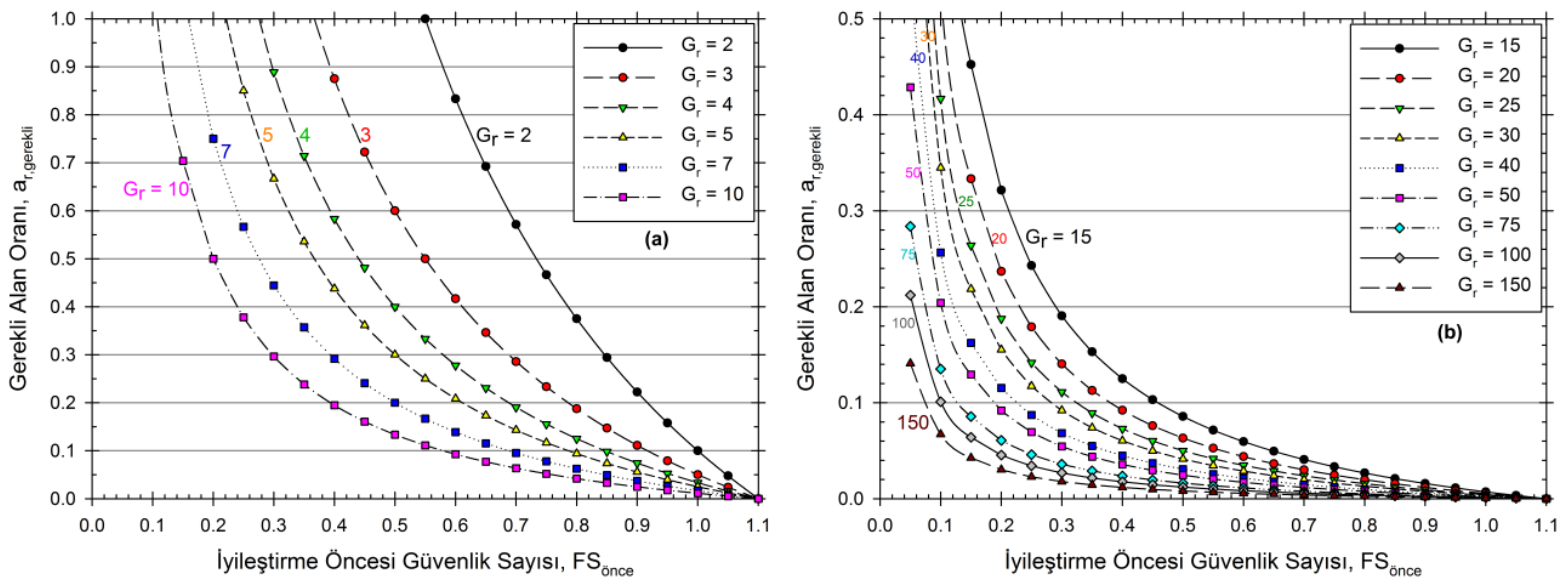

Şekil 12: Baez (1995)'e dayalı olarak sıvılaşmaya karşı güvenlik sayısını 1.1'e yükseltmek için gerekli alan oranı
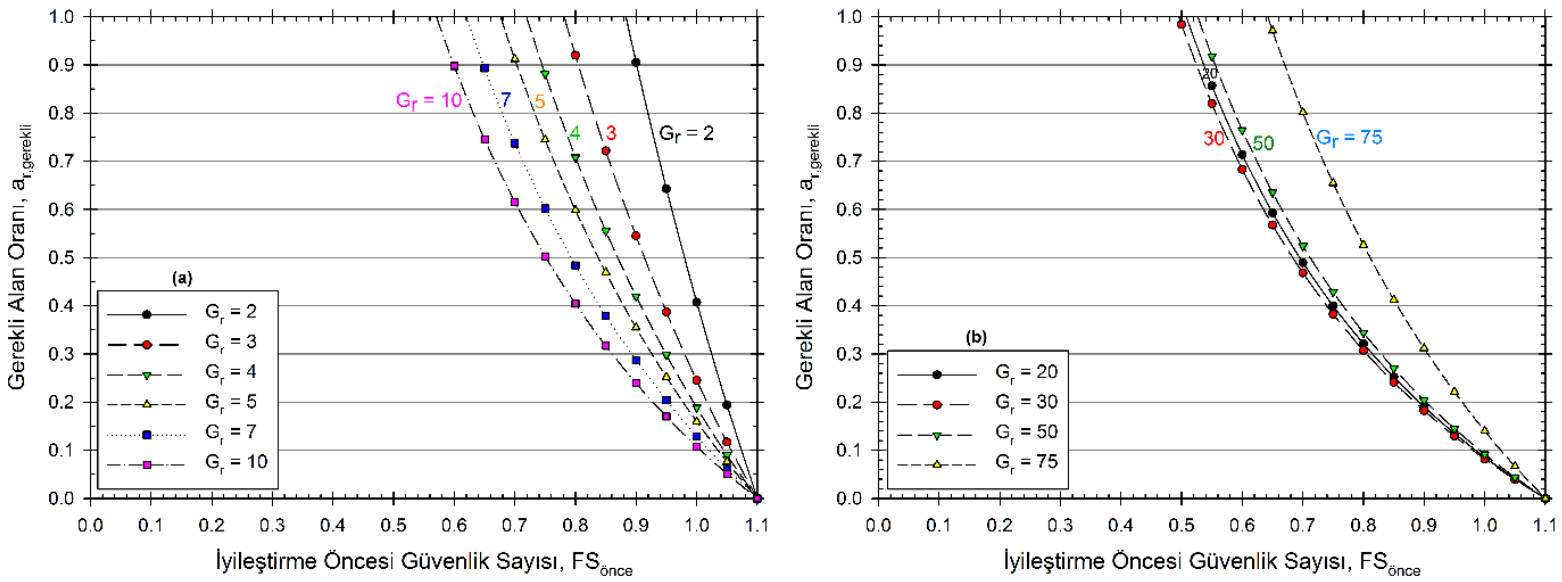

Şekil 13: Rayamajhi vd. (2014)'e dayalı olarak sıvılaşmaya karşı güvenlik sayısını 1.1'e yükseltmek için gerekli alan oranı 


\section{Sonuçlar}

Depremlerin mühendislik yapıları üzerinde yol açtığı hasarların en önemlilerinden birisi olan zemin sıvılaşmasına karşı güvenlik sayılarının ele alındığı bu çalışmada, yeni TBDY'nde tanımlanan zeminlerin SPT'ye dayalı sıvılaşma analizi için bir seri analiz gerçekleştirilmiştir. Çalışma kapsamında, tipik bir arazi modelinde $1.0 \mathrm{~g}$ 'lik pik yatay yer ivmesi ve 7.5 büyüklügündeki deprem için farklı derinlikler, yeraltı su seviyeleri, ince dane oranları ve SPT-N değerlerine ait sıvılaşmaya karşı güvenlik sayıları elde edilmiş ve pratik kullanıma uygun hale getirilmiştir. Çalışmada elde edilen grafikler, tanımlanan düzeltme faktörleri ve interpolasyon yöntemi sayesinde farklı pik yatay yer ivmesi, deprem büyüklükleri ve arazi ölçümleri için de kullanılabilir hale getirilmiştir. Bu çalışmadaki verilen grafiklerin, oldukça çok parametre ve ampirik ifade eden prosedür ile elde edilen güvenlik sayılarını basit ve doğru bir şekilde veriyor oluşu, grafiklerin uygulamada pratik bir alternatif olabileceğini göstermektedir. Ayrıca, sıvılaşma riski olduğu belirlenen zeminlerin özellikle jetgrout gibi zemin içerisinde kolon teşkili şeklinde uygulanan yöntemler ile iyileştirilmesinin istenmesi durumunda, seçilmesi gereken kolon rijitliklerinin ve aralıklarının optimum tasarımını sağlayabilmek için literatürde yer alan iki farklı yaklaşıma göre tasarım kartları geliştirilmiştir. Önerilen bu tasarım kartları, zemin etüt raporları için hazırlanan sıvılaşma analizleri ve sıvılaşmaya karşı iyileştirme çalışmalarında oldukça yararlı olabilecektir.

\section{Kaynaklar}

Baez J.I., (1995), A design model for the reduction of soil liquefaction by vibro-stone columns, Doktora Tezi, The University of Southern California, USA.

Boulanger R.W., Idriss I.M., (2014), CPT and SPT based liquefaction triggering procedures, Report No. UCD/CGM-14/01, Center for Geotechnical Modeling, University of California at Davis, 138ss.

Bray J.D., Dashti S., (2010), Liquefaction-induced movements of buildings with shallow foundations, International Conferences on Recent Advances in Geotechnical Earthquake Engineering and Soil Dynamics, Paper No. OSP 2, 24-29 May, San Diego, California.

Bray J.D., Sancio R.B., Durgunoglu H.T., Onalp A., Youd L., Stewart J.P., Seed R.B., Cetin K.O., Bol E., Baturay M.B., Christensen C., Karadayilar T., (2004), Subsurface characterization at ground failure sites in Adapazari, Turkey, Journal of Geotechnical and Geoenvironmental Engineering, 130(7), 673-685.

Cetin K.O., Seed R.B., Der Kiureghian A., Tokimatsu K., Harder L.F., Kayen R.E., Moss R.E.S., (2004b), Standard penetration testbased probabilistic and deterministic assessment of seismic soil liquefaction potential, Journal of Geotechnical and Geoenvironmental Engineering, 130(12), 1314-1340.

Cetin K.O., Youd T.L., Seed R.B., Bray J.D., Stewart J.P., Durgunoglu H.T., Lettis W., Yilmaz M.T., (2004a), Liquefaction-induced lateral spreading at Izmit Bay during the Kocaeli (Izmit)-Turkey earthquake, Journal of Geotechnical and Geoenvironmental Engineering, 130(12), 1300-1313.

Durgunoğlu H.T., (2004), Yüksek modüllü kolonların temel mühendisliğinde kullanımı, Türkiye Mühendislik Haberleri, 431, $39-52$.

Idriss I.M., Boulanger R.W., (2008), Soil liquefaction during earthquakes, Earthquake Engineering Research Institute, EERI Publication, Monograph MNO-12, Oakland, CA, 237ss.

Idriss I.M., Boulanger R.W., (2010), SPT-based liquefaction triggering procedures, Report No. UCD/CGM-10/02, Center for Geotechnical Modeling, University of California at Davis, 259ss.

Liao S.S.C., Whitman R.V., (1986), Overburden correction factors for SPT in sand, Journal of Geotechnical Engineering, 112(3), $373-$ 377.

Mollamahmutoglu M., Kayabali K., Beyaz T., Kolay E., (2003), Liquefaction-related building damage in Adapazari during the Turkey earthquake of August 17, 1999, Engineering Geology, 67, 297-307.

Ozener P., Dulger M., Berilgen M., (2015), Numerical study of effectiveness of jet-grout columns in liquefaction mitigation, 6th International Conference on Earthquake Geotechnical Engineering, Christchurch, New Zealand.

Özsoy B., Durgunoğlu T., (2003), Sıvılaşma etkilerinin yüksek kayma modüllü zemin - çimento karışımı kolonlarla azaltılması, 5. Ulusal Deprem Mühendisliği Kongresi, Bildiri No: AT-004, 26-30 Mayıs, İstanbul.

Rayamajhi D., Nguyen T.V., Ashford S.A., Boulanger R.W., Lu J., Elgamal A., Shao L., (2014), Numerical study of shear stress distribution for discrete columns in liquefiable soils, Journal of Geotechnical and Geoenvironmental Engineering, 140(3), 04013034: 1-9.

Seed H.B., Idriss I.M., (1971), Simplified procedure for evaluating soil liquefaction potential, Journal of the Soil Mechanics and Foundations Division, 97(9), 1249-1273.

Sivrikaya O., Toğrol E., (2009), Arazi deneyleri ve geoteknik tasarımda kullanımları, Birsen Yayınevi, İstanbul, 280ss.

TBDY, (2018), Türkiye Bina Deprem Yönetmeliği, Resmi Gazete, Tarih: 18.03.2018, Sayı: 30364.

Youd T.L., Idriss I.M., Andrus R.D., Arango I., Castro G., ..., Stokoe K.H., (2001), Liquefaction resistance of soils: Summary report from the 1996 NCEER and 1998 NCEER/NSF workshops on evaluation of liquefaction resistance of soils, Journal of Geotechnical and Geoenvironmental Engineering, 127(10), 817-833. 